Etty Susilowati*, Mohammad Guntur Ardhita Putra Budiluhur University, Faculty of Economics and Business, International Business and Management Studies, Indonesia

\title{
Smartphone Brand Loyalty and Consumer Heterogeneity
}

DOI: 10.7595/management.fon.2020.0007

Abstract:

Research Question: The purpose of this study is to examine the effect of sales promotion and advertisement on brand association and brand loyalty of Samsung smartphones via the analysis of gender and age as moderating variables. Motivation: The motivation for this study emerges from the fact that the effect of sales promotion and advertisement on brand loyalty have not considered the effects of consumer heterogeneity such as age and gender. Idea: The core idea of this study is to verify the effect of monetary promotion, non-monetary promotion, perceived advertising, and individual attitude towards brand association and brand loyalty through the moderate effects of age and gender. Data: This research was carried out in South Jakarta, Indonesia by employing a simple random sampling method and questionnaires distributed to 100 respondents. Tools: Data were analyzed by using Partial Least Square Structural Equation (PLS-SEM) method and the SmartPLS 3.0 software. The PLS-SEM was performed with a two-step approach by analyzing the outer and inner model, afterwards followed by a multi-group analysis to analyze moderating effects of both variables of gender and age. Findings: The findings indicate that non-monetary promotion and individual attitude towards advertising significantly affect brand association while brand association significantly affects brand loyalty. Gender and age-specific analyses indicate that gender differences significantly moderate the influence of individual attitude towards advertising on brand association and age differences significantly moderate the effect of monetary promotion on brand association. Moreover, women, men, younger and older consumers behave differently towards sales promotion. Contribution: This study contributes to the literature by adding empirical evidences in terms of how different consumers respond to sales promotion and advertising as well as further effects on brand association and brand loyalty.

Keywords: sales promotion, advertisement, brand association, brand loyalty, age, gender

JEL Classification: M31, M37

\section{Introduction}

Nowadays, marketing is a very important aspect of a company's life, without proper marketing strategies of which companies will not be able to enter and maintain the product life cycles. Currently, the marketers face high challenges to take up the appropriate marketing strategies due to a high variety of the products, high customer expectations and rapid industrial growths. Samsung Electronics Co., Ltd. is a South Korean multinational electronics company headquartered in Suwon, South Korea. It is the flagship division of the Samsung Group, which accounts for 70\% of the group's revenue in 2012 (Klimes, 2019). It is the world's second largest information technology company by revenue, after Apple Inc. (Forbes, 2019). Samsung Electronics has assembled sales networks in 80 countries and employs around 370,000 people (SHAMS, 2016). Data indicated that in 2015 and 2014, Samsung smartphones had the highest shipment volume and market share compared to competitors' brands such as Apple, Huawei, Lenovo, and Xiaomi. The shipment volumes reached the value of 324.8 million units in 2015, which was higher than Apple (231.5 million units), Huawei (106.6 million units), Lenovo (74 million units), and Xiaomi (70.8 million units). The market share of Samsung in 2015 reached the value of $22.7 \%$, which was higher than Apple (16.2\%), Huawei (7.4\%), Lenovo (5.2\%), and Xiaomi (4.9\%). The same condition also applied in 2014 where Samsung still led both in shipment volumes and market share in comparison with the other four brands (IDC, 2016). The high popularity of Samsung smart 
phones in Indonesia is not separated from the role of sales promotion and advertising conducted by the company. The company claims to control $50 \%$ of the smartphone market share in Indonesia. A majority of their consumers are loyal consumers (Wardani, 2019). Some marketing strategies undertaken by this company to maintain its market share, including conducting market research, developing related business ecosystems such as providing operator services and developing applications, as well as building partnerships with retail business partners to distribute its products (Arum, 2013). Previous studies have proven positive relationships between sales promotion and advertisement on brand association and brand loyalty (Valette-Florence, Guizani, \& Merunka, 2011; Buil, De Chernatony, \& Martínez, 2013; Boyland, \& Halford, 2013). In this study, we examine the effect of sales promotion and advertisement on brand associations and brand loyalty of Samsung smartphones through an analysis of gender and age as moderating variables. This is because the two variables have been verified to significantly affect consumer behavior in the prior studies (Verhaeghen, Marcoen, \& Goossens, 1993; Loo, 2000; Finucane, Slovic, Hibbard, Peters, Mertz, \& MacGregor, 2002; Strough, Cheng, \& Swenson (2002); Ellen, Hess Thomas, Daniel, \& Corinne, 2007; Bruine de Bruin, Parker, \& Fischhoff, 2007; Sun, Fang, \& Lim, 2012; Huang \& Benyoucef, 2017). Prior studies have not considered the effects that resulted from consumer heterogeneity (age and gender). Therefore, this study contributes to the literature in adding empirical evidence to how male and female consumers as well as younger and the older groups respond to sales promotions and advertisements offered by companies and the effects on creating brand associations and brand loyalty. The remaining part of this study is organized as follows: we will explain the literature review, the hypotheses development, and the proposed structural model in the next section. In the third section, we will further explain the sampling, measurements and data analysis, followed by the findings and discussion in the fourth section and finally with the conclusions of the study.

\section{Literature Review}

This section will briefly describe the variables used in this study based on the theories and previous studies. It is used as the rationalization for the hypothesis development and the structural model. The variables are monetary and non-monetary sales promotion, perceived advertising, brand associations, brand loyalty, as well as gender and age as moderating variables.

\subsection{Sales promotion}

Sales promotion is one of the five aspects of the promotional mix which the other four aspects are advertising, personal selling, direct marketing and publicity or public relations (Rowley, 1998). Sales promotion can be undertaken in the form of product display, contest, voucher, free product, gift, discount price, and rebate (Tellis, 1998). All these tools are used to increase product sales in the short run (Kotler \& Amstrong, 1997; Kotler \& Amstrong, 2008) while sales promotion is proved to increase demand and positively affect consumer purchasing behavior (Greenleaf \& Lehmann, 1995; Laroche, Kim, \& Zhou, 1996; Thomas \& Menon, 2007; Santini, Sampaio, Perin, \& Vieira, (2015); Luxton \& Brito, 2015). On the contrary, this variable proved to have positive and negative effects on brand equity. Monetary sales promotion such as discounts or coupons is proved to negatively affect brand equity (Yoo, Donthu, \& Lee, 2000). This is because most consumers set the price as one indicator of product quality. Providing discounts or coupons will result in price reductions and decline the consumers' perceptions of product quality (Agarwal \& Teas, 2002; DelVecchio, Henard, \& Freling, 2006). Non-monetary sales promotion, however, has the opposite effect in which the provision of free products and gifts proves to increase the brand's product equity (Chu \& Keh, 2006; Palazón and Delgado-Ballester, 2009; Buil et al., 2013). According to the above explanations, the hypotheses that will be tested in this study are:

Hypothesis 1. Monetary promotion has a negative effect on brand association

Hypothesis 2. Non-monetary promotion has a positive effect on brand association

\subsection{Advertising}

Advertising is a form of non-personal marketing communication that gives information about products and services or ideas through various media such as newspapers, magazines, television, radio, outdoor advertising, or online media such as search results, blogs, or websites (Bovee, 1992). Advertising is differentiated from public relations in that an advertiser usually pays for and has control over the message. It is differentiated from personal selling in that the message is non-personal, i.e., not directed to a particular individual. Advertising is communicated through various mass media. Previous studies have been carried out to ana- 
lyze a broader impact of these variables on attracting consumers' attention (Nettelhorst \& Brannon, 2012), increasing sales (Kotler \& Amstrong, 2010; Akanbi \& Adeyeye, 2011), and affecting consumer attitudes towards products (Jeong \& Jang, 2016 ; Shareef et al., 2017; Stroup \& Branstetter, 2018), whereas according to Hasan (2010) and Goodrich (2014), the gender difference also serves as a moderating role in influencing consumer behavioral intention. To examine the effect of advertising on brand equity, Buil et al. (2013) utilizes perceived advertising and individual attitudes towards advertising. Perceived advertising is the consumer's perception of how much advertising the company is doing. The more advertising applied, the more inheriting a brand in the minds of consumers. Meanwhile, the consumer's perception of the attributes and brand quality of products affects the individual attitudes towards advertising (Buil et al., 2013). According to the above explanations, the hypotheses that will be tested in this study are:

Hypothesis 3. Perceived advertising has a positive effect on brand association

Hypothesis 4. Individual attitude towards advertising has a positive effect on brand association

\subsection{Brand associations and brand loyalty}

Brand association and brand loyalty are elements of the brand equity. These two variables are the two highest dimensions of brand equity (Aaker, 2009). Brand association is a collection of information and impressions attached to a consumer's memory of a particular brand (Aaker, 2009) while brand loyalty is the commitment of consumers to make a consistent purchase of a particular brand of product or service without being affected by the influence of a competitor's brand (Oliver, 2014). Brand equity is a set of branded assets that can subtract the value provided by the products or services to companies and customers (Aaker, 2009). Brand association and brand loyalty have significantly affected brand equity (Yoo, et al., 2000). Brand association is also sometimes considered as brand awareness (Yoo et al., 2000). The positive relationship of brand association and brand loyalty has been proven by Keller \& Lehmann (2003), Pappu, Quester, \& Cooksey, (2005), \& Buil et al., 2013). In addition, there is a positive relationship between sales promotion, advertisement and brand equity (Valette-Florence et al., 2011; Buil et al., 2013; Boyland, \& Halford, 2013). The results of prior studies indicate a positive relationship of sales promotion and advertising on brand equity. According to the above explanations, the hypothesis that will be tested in this study is:

Hypothesis 5. Brand association has a positive effect on brand loyalty

\subsection{Gender and age considerations}

Gender and age have been proven to affect consumer purchasing decisions (Sun et al., 2012; Huang \& Benyoucef, 2017). When purchasing, women tend to access all information related to the product or service they want to buy, whereas males only access some of the information that is perceived as trustworthy and important (Yang \& Chen, 2010). In addition, females are more affected by others and environments than males (Tamres, Janicki, \& Helgeson, 2002). Mazumdar \& Papatla (1995), Harmon \& Hill (2003), and Kwon \& Kwon (2007) prove that women are affected by the type of promotion that affects transactional prices such as coupons, but more likely to be affected by the type of promotion affecting acquisition values such as rebates and non-monetary promotions. Besides, females are affected by more verbal than visual advertisements (Putrevu, 2014). In addition to gender, another factor that significantly affects purchasing decisions is consumer age. Some research suggests that the ability of consumers to make rational decisions is diminished in the older group (Verhaeghen et al.,1993; Loo, 2000; Ellen et al., 2007) while other studies suggest that the older group make more rational and intuitive decisions than the younger group (Bruine de Bruin et al., 2007). Also, the older group is more likely to delegate decisions than the younger group (Finucane et al., 2002; Strough et al., 2002). According to the above explanations, the hypotheses that will be tested are:

Hypothesis 6a. The effect of monetary promotion on brand association is moderated by gender Hypothesis $6 \mathrm{~b}$. The effect of non-monetary promotion on brand association is moderated by gender Hypothesis $6 \mathbf{c}$. The effect of perceived advertising on brand association is moderated by gender Hypothesis $6 \mathbf{d}$. The effect of individual attitude on brand association is moderated by gender Hypothesis $6 e$. The effect of brand association on brand loyalty is moderated by gender Hypothesis $7 a$. The effect of monetary promotion on brand association is moderated by age Hypothesis $\mathbf{7 b}$. The effect of non-monetary promotion on brand association is moderated by age Hypothesis 7c. The effect of perceived advertising on brand association is moderated by age Hypothesis $\mathbf{7 d}$. The effect of individual attitude on brand association is moderated by age Hypothesis $7 e$. The effect of brand association on brand loyalty is moderated by age 


\section{Methodology}

\subsection{Sampling and measurements}

Questionnaires with five-point Likert scales ( $1=$ strongly disagree; $5=$ strongly agree) were distributed to 130 smartphone owners in South Jakarta, Indonesia. The samples were selected through random sampling method and the questionnaires were distributed by using google forms from August until December 2018. Sales promotions are segmented into monetary and non-monetary promotions following Buil et al. (2013). Monetary promotions consist of price discounts $(X 1, X 2, X 3)$ and cashbacks $(X 4, X 5, X 6)$ while non-monetary promotions consist of free items $(X 7, X 8)$ and gifts $(X 9)$. In addition, advertising is segmented into perceived advertising and individual attitudes (Buil et al., 2013). Perceived advertising consists of varieties of online advertising (X10) and advertising media (X11) while individual attitudes consist of the capabilities of commercial TV smartphones to be remembered by consumers (X12), the ability of the smartphone company promoting the advantages of the smartphones in television advertising (X13), and the uniqueness of smartphone advertising (X14). Brand association is measured through the credibility of Samsung company (X15), the clear image of the type person who uses the brand (X16), whether the brand has a personality and is interesting (X17). Finally, brand loyalty is measured through the willingness of consumers to buy Samsung smartphones (X18), the brand as consumers' first choices, and the superiority of the brand compared to other brands, whether Samsung smartphones are the first consumer choice (X19), whether consumer prefers Samsung smartphones to other brands (X20) (Keller \& Lehmann, 2003; Pappu et al., 2005; Buil et al., 2013). More information can be found in Appendix A.1. The structural model is shown in Figure 1 below.

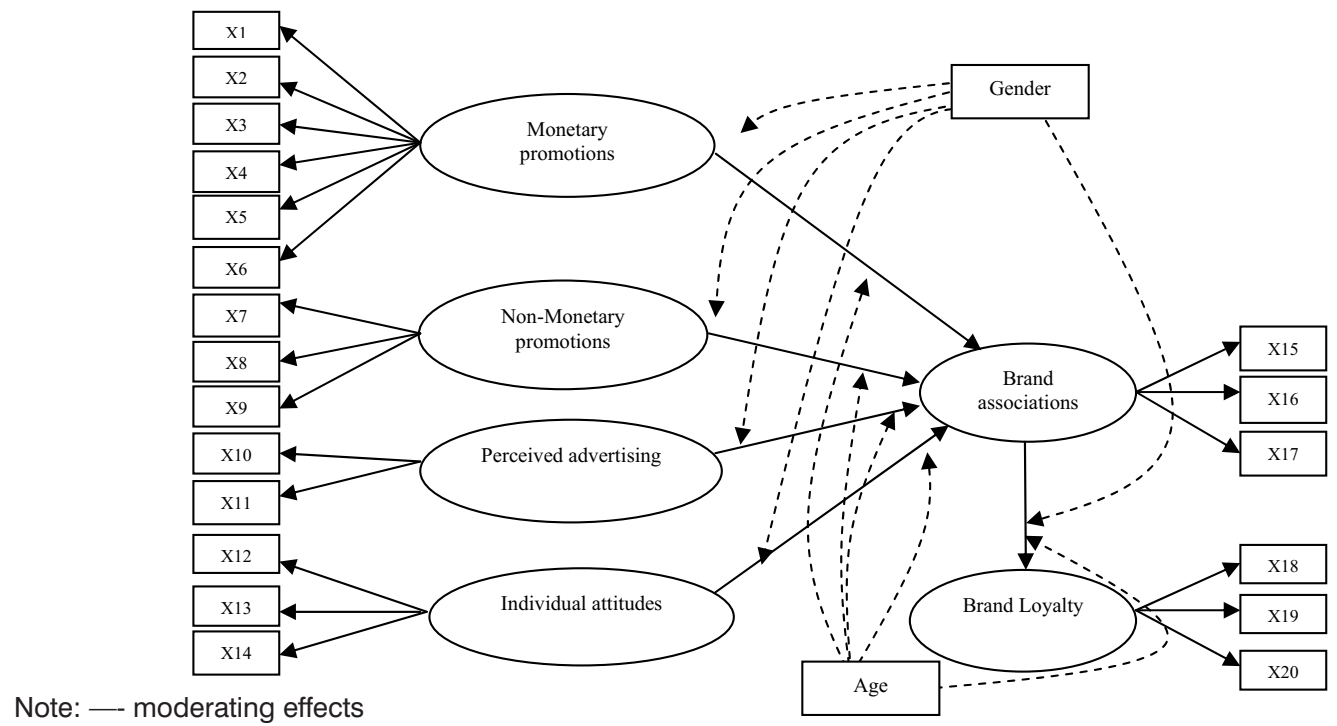

Figure 1: The structural model

\subsection{Data Analysis}

Data analysis was performed by using Partial Least Square Structural Equation (PLS-SEM) method and the SmartPLS 3.0 software. The use of this method is selected precisely because of the relatively small number of respondents causing covariance-based SEM analysis not possible to be applied. The PLS-SEM analysis was performed with a two-step approach by analyzing the outer model (evaluation of measurement model) and followed by analyzing the inner model (Yamin \& Kurniawan, 2011). First, the PLS-SEM analysis is performed on all data sets, followed by a multi-group analysis to analyze moderating effects of both variables of gender and age.

\section{Findings}

\subsection{Respondents characteristics}

In this study, we distributed questionnaires to 130 respondents. However, only 100 data were used since 30 respondents did not have any experience in using a Samsung Smartphone. The respondents sample consisted of university students (51\%), employees (26\%), high school students (18\%), and others (5\%) in South 
Jakarta. As many as $52 \%$ of respondents were women, while the other $48 \%$ were men. Based on age, $57 \%$ were aged 21 to $30,40 \%$ were aged less than 20 , and $3 \%$ were aged 31 to 40 . As many as $56 \%$ earn less

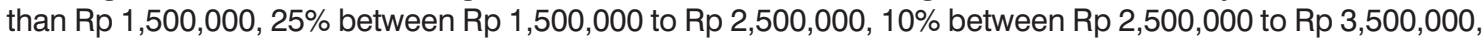
$6 \%$ between $\operatorname{Rp} 3,500,000$ to $\operatorname{Rp~4,500,000,~and~3\% ~more~than~} \operatorname{Rp~4,500,000.~}$

\subsection{PLS-SEM results}

The first analysis of PLS-SEM is an outer model analysis that is by evaluating the measurement model (Yamin \& Kurniawan, 2011). This evaluation is performed by looking at the result of convergent and discriminant validity. The result indicates that convergent validity has been attained. All values of factor loadings are $>0.50$ and t-statistics are $>2.0$. Moreover, the value of composite reliability and cronbach's alpha of all latent variables are $>0.70$. Finally, the Average Variance Extracted (AVE) value of all indicators are $>0.50$ (Fornell \& Larcker, 1981) (Table 1).

Table 1: Results of measurement model

\begin{tabular}{|c|c|c|c|c|c|c|}
\hline $\begin{array}{c}\text { Latent } \\
\text { variables }\end{array}$ & $\begin{array}{l}\text { Manifest } \\
\text { variables }\end{array}$ & $\begin{array}{l}\text { Standardized } \\
\text { regression } \\
\text { coefficients }\end{array}$ & $\begin{array}{c}\text { Average } \\
\text { Variance } \\
\text { Extracted } \\
\text { (AVE) }\end{array}$ & $\begin{array}{c}\text { Composite } \\
\text { reliability }\end{array}$ & $\begin{array}{c}\text { Cronbach's } \\
\text { Alpha }\end{array}$ & Rho A \\
\hline \multirow{6}{*}{$\begin{array}{l}\text { Monetary } \\
\text { promotion }\end{array}$} & $\mathrm{X} 1$ & $0.769 * \star \star$ & \multirow{6}{*}{0.525} & \multirow{6}{*}{0.868} & \multirow{6}{*}{0.818} & \multirow{6}{*}{0.831} \\
\hline & $\mathrm{X} 2$ & $0.636^{\star \star *}$ & & & & \\
\hline & $\mathrm{X3}$ & $0.736^{\star \star \star}$ & & & & \\
\hline & $X 4$ & $0.719 * \star \star$ & & & & \\
\hline & $\mathrm{X} 5$ & $0.739 * * \star$ & & & & \\
\hline & $\mathrm{X} 6$ & $0.739^{\star \star \star}$ & & & & \\
\hline \multirow{3}{*}{$\begin{array}{l}\text { Non-monetary } \\
\text { promotion }\end{array}$} & $\mathrm{X} 7$ & $0.798 * * \star$ & \multirow{3}{*}{0.723} & \multirow{3}{*}{0.887} & \multirow{3}{*}{0.813} & \multirow{3}{*}{0.848} \\
\hline & $\mathrm{X8}$ & $0.872^{\star \star \star}$ & & & & \\
\hline & $\mathrm{X9}$ & $0.879 * \star \star$ & & & & \\
\hline \multirow{2}{*}{$\begin{array}{l}\text { Perceived } \\
\text { advertising }\end{array}$} & $\mathrm{X} 10$ & $0.928 * \star \star$ & \multirow{2}{*}{0.748} & \multirow{2}{*}{0.855} & \multirow{2}{*}{0.679} & \multirow{2}{*}{0.790} \\
\hline & $\mathrm{X} 11$ & $0.796 * \star \star$ & & & & \\
\hline \multirow{3}{*}{$\begin{array}{l}\text { Individual } \\
\text { attitude } \\
\text { towards } \\
\text { advertising }\end{array}$} & $\mathrm{X} 12$ & $0.883^{\star \star \star}$ & \multirow{3}{*}{0.710} & \multirow{3}{*}{0.880} & \multirow{3}{*}{0.796} & \multirow{3}{*}{0.812} \\
\hline & $\mathrm{X} 13$ & $0.781^{\star \star \star}$ & & & & \\
\hline & $\mathrm{X} 14$ & $0.860^{\star \star *}$ & & & & \\
\hline \multirow{3}{*}{$\begin{array}{c}\text { Brand } \\
\text { association }\end{array}$} & $\mathrm{X} 15$ & $0.935^{\star \star \star *}$ & \multirow{3}{*}{0.816} & \multirow{3}{*}{0.930} & \multirow{3}{*}{0.887} & \multirow{3}{*}{0.901} \\
\hline & $\mathrm{X} 16$ & $0.863^{\star * \star}$ & & & & \\
\hline & $\mathrm{X} 17$ & $0.911^{\star \star \star}$ & & & & \\
\hline \multirow{3}{*}{ Brand loyalty } & $\mathrm{X} 18$ & $0.895^{\star \star \star}$ & \multirow{3}{*}{0.748} & \multirow{3}{*}{0.878} & \multirow{3}{*}{0.790} & \multirow{3}{*}{0.800} \\
\hline & $\mathrm{X} 19$ & $0.856^{\star \star \star}$ & & & & \\
\hline & $\mathrm{X} 20$ & $0.764^{\star \star \star}$ & & & & \\
\hline
\end{tabular}

Note: ${ }^{* * *} p<0.01 ; * * p<0.05 ;{ }^{*} p<0.10$

Source: processed data

The next evaluation is to assess discriminant validity by looking at the cross loadings of each manifest variable with the latent variables. The model is deduced to have good discriminant validity when the correlation between the manifest variable is higher against the latent variables in comparison with the other latent variables (Yamin \& Kurniawan, 2011). Table 2 summed up that the condition has been attained. 
Table 2: Cross loadings results

\begin{tabular}{|c|c|c|c|c|c|c|}
\hline & $\begin{array}{c}\text { Monetary } \\
\text { promotion }\end{array}$ & $\begin{array}{c}\text { Non-monetary } \\
\text { promotion }\end{array}$ & $\begin{array}{c}\text { Perceived } \\
\text { advertising }\end{array}$ & $\begin{array}{c}\text { Individual } \\
\text { attitudes } \\
\text { towards } \\
\text { advertising }\end{array}$ & $\begin{array}{c}\text { Brand } \\
\text { association }\end{array}$ & $\begin{array}{c}\text { Brand } \\
\text { loyalty }\end{array}$ \\
\hline X1 & 0.769 & 0.391 & 0.333 & 0.309 & 0.432 & 0.408 \\
\hline X2 & 0.636 & 0.236 & 0.261 & 0.184 & 0.253 & 0.292 \\
\hline X3 & 0.736 & 0.423 & 0.201 & 0.123 & 0.315 & 0.352 \\
\hline X4 & 0.719 & 0.555 & 0.195 & 0.312 & 0.333 & 0.395 \\
\hline X5 & 0.739 & 0.570 & 0.272 & 0.418 & 0.355 & 0.415 \\
\hline X6 & 0.739 & 0.586 & 0.285 & 0.319 & 0.333 & 0.392 \\
\hline X7 & 0.457 & 0.798 & 0.222 & 0.262 & 0.345 & 0.318 \\
\hline X8 & 0.539 & 0.872 & 0.156 & 0.174 & 0.449 & 0.417 \\
\hline X9 & 0.615 & 0.879 & 0.317 & 0.335 & 0.547 & 0.499 \\
\hline X10 & 0.382 & 0.285 & 0.928 & 0.620 & 0.420 & 0.455 \\
\hline X11 & 0.207 & 0.180 & 0.796 & 0.340 & 0.258 & 0.261 \\
\hline X12 & 0.367 & 0.290 & 0.457 & 0.883 & 0.374 & 0.438 \\
\hline X13 & 0.188 & 0.247 & 0.445 & 0.781 & 0.318 & 0.332 \\
\hline X14 & 0.406 & 0.240 & 0.563 & 0.860 & 0.425 & 0.415 \\
\hline X15 & 0.436 & 0.542 & 0.366 & 0.452 & 0.935 & 0.805 \\
\hline X16 & 0.394 & 0.424 & 0.327 & 0.304 & 0.863 & 0.647 \\
\hline X17 & 0.449 & 0.488 & 0.408 & 0.438 & 0.911 & 0.815 \\
\hline X18 & 0.504 & 0.492 & 0.448 & 0.547 & 0.776 & 0.895 \\
\hline X19 & 0.338 & 0.385 & 0.259 & 0.326 & 0.693 & 0.856 \\
\hline X20 & 0.473 & 0.364 & 0.382 & 0.297 & 0.650 & 0.764 \\
\hline
\end{tabular}

Source: processed data

The second analysis of PLS-SEM is the inner model analysis by evaluating the structural model (Yamin \& Kurniawan, 2011). This evaluation is performed by looking at the path coefficients, R-square values, and multicollinearity between variables. Non-monetary promotion and individual attitude towards advertising significantly affect brand associations (coef. $=0.370$; $p$-value $=0.05$ and coef. $=0.207$; $p$-value $=0.05$, respectively). Therefore, hypotheses 2 and 4 are statistically supported. Non-monetary promotion has a greater effect on brand association than individual attitude towards advertising. In contrast, monetary promotion and perceived advertising do not significantly affect brand association. Furthermore, brand association significantly affects brand loyalty (coef. $=0.843 ; \mathrm{p}$-value $=0.01$ ). Therefore hypothesis 5 is statistically supported (Table 3 ). The R-square values indicates that the value of brand association is $40.1 \%$ and the brand loyalty is $71.1 \%$. According to Latan \& Ramli (2013), the values above 0.40 and 0.75 denote moderate and strong models, respectively. The result of Variance Inflation Factor (VIF) values all variables are $<3$ indicate the absence of multicollinearity.

Table 3: Path coefficients

\begin{tabular}{|l|c|c|c|}
\hline \multicolumn{1}{|c|}{ Structural path } & $\begin{array}{c}\text { Direct } \\
\text { effect }\end{array}$ & $\begin{array}{c}\text { Indirect } \\
\text { effect }\end{array}$ & $\begin{array}{c}\text { Total } \\
\text { effect }\end{array}$ \\
\hline Monetary promotion -> Brand association & 0.102 & - & 0.102 \\
\hline Monetary promotion -> Brand loyalty & - & 0.086 & 0.086 \\
\hline Non-monetary promotion -> Brand association & 0.370 & - & $0.370^{\star *}$ \\
\hline Non-monetary promotion -> Brand loyalty & - & 0.312 & $0.312^{\star *}$ \\
\hline Perceived advertising -> Brand association & 0.147 & - & 0.147 \\
\hline Perceived advertising -> Brand loyalty & - & 0.124 & 0.124 \\
\hline Individual attitude towards advertising -> Brand association & 0.207 & - & $0.207^{\star *}$ \\
\hline Individual attitude towards advertising -> Brand loyalty & - & 0.175 & $0.175^{\star *}$ \\
\hline Brand association -> Brand loyalty & 0.843 & - & $0.843^{\star \star *}$ \\
\hline
\end{tabular}

Source: processed data

Notes: ${ }^{* *} p<0.01 ;{ }^{* *} p<0.05 ;{ }^{*} p<0.10$ 
The relationship of all variables is presented in Figure 2 below.

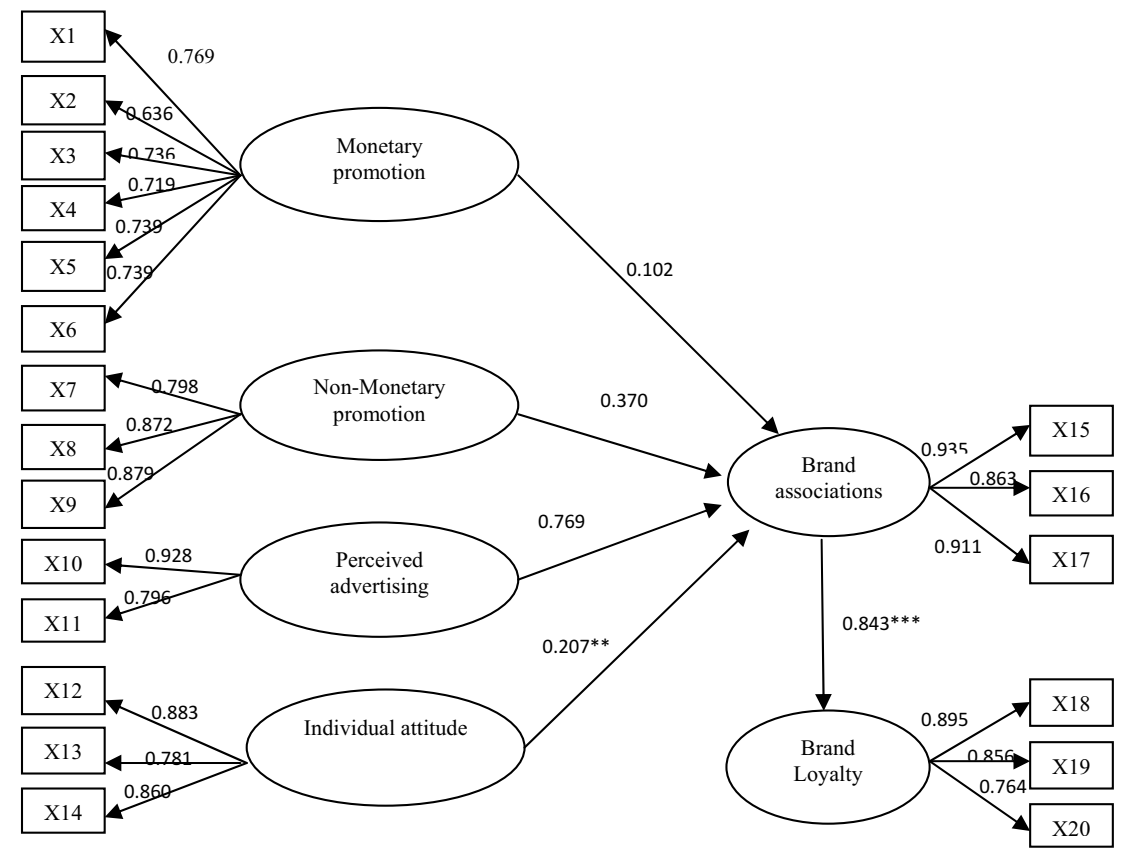

Figure 2: Structural result of PLS-SEM

\subsection{Moderating effects analyses}

To capture the moderating effects of gender and age, Partial Least Square Multi Group Analysis (PLS-MGA) was applied to the dataset following Henseler, Ringle, \& Sinkovics (2009) and Hew, Badaruddin, \& Moorthy (2017). As proposed by Hew et al. (2017), 5000 bootstrapping samples were used for robust group comparison results. The results of PLS-MGA with gender as moderating variable are summed up in Table 4. Gender differences are judged as significant if P-value $>0.90$ (Hew et al., 2017). Gender differences significantly moderate the effect of individual attitude towards advertising on brand association while the effect is relatively higher in women (coef. $=0.374 ; p$-value $=0.05$ and coef. $=0.048 ; p$-value $=0.05$, respectively). Therefore, hypothesis $6 \mathrm{~d}$ is supported. The R-square values of brand associations and brand loyalty are $45.8 \%$ and $73.7 \%$, respectively.

Table 4: PLS-MGA results of gender as a moderating variable

\begin{tabular}{|c|c|c|c|c|c|}
\hline Hypotheses & Paths & Men & Women & $\begin{array}{c}\text { Path coef.- } \\
\text { differences }\end{array}$ & $\begin{array}{c}\text { P- } \\
\text { Value }\end{array}$ \\
\hline $\mathrm{H6a}$ & Monetary promotion -> Brand association & -0.015 & 0.027 & 0.041 & 0.563 \\
\hline $\mathrm{H} 6 \mathrm{~b}$ & $\begin{array}{c}\text { Non-Monetary promotion -> Brand } \\
\text { association }\end{array}$ & $0.623^{\star \star \star}$ & $0.311^{\star *}$ & 0.313 & 0.102 \\
\hline $\mathrm{H} 6 \mathrm{c}$ & Perceived advertising - B Brand association & $0.242^{\star *}$ & 0.188 & 0.054 & 0.420 \\
\hline $\mathrm{H} 6 \mathrm{~d}$ & Individual attitude -> Brand association & 0.048 & $0.374^{\star *}$ & 0.326 & 0.935 \\
\hline $\mathrm{H} 6 \mathrm{e}$ & Brand association -> Brand loyalty & $0.850^{\star \star \star}$ & $0.858^{\star \star \star}$ & 0.008 & 0.575 \\
\hline
\end{tabular}

$$
\begin{gathered}
\text { Source: processed data } \\
\text { Notes: } \\
{ }^{* * *} p<0.01 ;{ }^{* *} p<0.05 ;{ }^{*} p<0.10
\end{gathered}
$$

Furthermore, the result of PLS-MGA with age as a moderating variable is summed up in Table 5. Consumer age is segmented into two; less than and over 20 years of age. The age differences significantly moderate the influence of monetary promotion on brand association in which the effect of monetary promotion is positive for the the older group (coef. $=0.072 ; p$-value $=0.01$ and coef. $=0.424 ; p$-value $=0.01$, respectively). Be- 
sides, age differences also significantly moderate the effect of individual attitude towards advertising on brand association while the negative effects are found in the older group (coef. $=0.290 ; p$-value $=0.10)$ and positive in the younger group (coef. $=0.249 ; p$-value $=0.10$ ). Hence hypotheses $7 \mathrm{a}$ and $7 \mathrm{~d}$ are statistically supported. The R-square values of brand association and brand loyalty are $43 \%$ and $72.3 \%$, respectively.

Table 5: PLS-MGA results of age as a moderating variable

\begin{tabular}{|c|c|c|c|c|c|}
\hline Hypotheses & Paths & Age $<20$ & Age $>20$ & $\begin{array}{l}\text { Path coef.- } \\
\text { differences }\end{array}$ & P-Value \\
\hline $\mathrm{H} 7 \mathrm{a}$ & $\begin{array}{l}\text { Monetary promotion -> Brand } \\
\text { association }\end{array}$ & -0.072 & $0.424^{\star * \star}$ & 0.495 & 0.951 \\
\hline $\mathrm{H} 7 \mathrm{~b}$ & $\begin{array}{l}\text { Non-Monetary promotion -> Brand } \\
\text { association }\end{array}$ & $0.492^{*}$ & $0.383^{\star *}$ & 0.109 & 0.388 \\
\hline $\mathrm{H} 7 \mathrm{c}$ & $\begin{array}{l}\text { Perceived advertising -> Brand } \\
\text { association }\end{array}$ & 0.133 & 0.286 & 0.153 & 0.707 \\
\hline $\mathrm{H} 7 \mathrm{~d}$ & $\begin{array}{l}\text { Individual attitude towards } \\
\text { advertising }->\text { Brand association }\end{array}$ & 0.249 & $-0.290^{*}$ & 0.539 & 0.034 \\
\hline $\mathrm{H} 7 \mathrm{e}$ & Brand association -> Brand loyalty & $0.857^{\star * *}$ & $0.862^{* * *}$ & 0.004 & 0.549 \\
\hline
\end{tabular}

\section{Discussion}

According to the empirical analysis results, it is proved that non-monetary promotion and individual attitude towards advertising significantly affect brand association of Samsung smartphones. Non-monetary promotion has a positive effect on brand association. The result has supported Chu \& Keh (2006), Palazón \& Delgado-Ballester (2009), as well as Buil et al. (2013). In contrast, monetary promotion has no significant effect on brand association. Individual attitude towards advertising also has a positive effect on brand association of Samsung smartphones. The result has supported Buil et al. (2013) and Kotler \& Keller (2007). There are three key factors to consider, namely 1) the quality of the advertised message, 2) the way the message is delivered, and 3) the frequency of the message delivered. To that end, a more qualified, creative and attractive advertisement will influence consumers and brand association (Moorthy \& Hawkins, 2005; Keller, Parameswaran, \& Jacob, 2011). Perceived advertising including media and frequency of advertising does not significantly affect brand association of Samsung smartphones. The empirical results also indicate that brand association has a positive effect on brand loyalty. The result has supported Keller \& Lehmann (2003), Pappu et al. (2005), \& Buil et al. (2013).

Furthermore, the result of empirical analysis by incorporating gender as moderating variable indicates that, from the five hypotheses tested, only the effect of individual attitude towards advertising towards brand association is moderated by the differences between men and women (hypothesis $6 \mathrm{~d}$ ) while individual attitude towards advertising has no effect against brand association in men. Moreover, the results obtained by using age as a moderating variable indicate that the differences of consumer age only moderate the effect of monetary promotions on brand associations (hypothesis 7a) while in younger consumers the effect of monetary promotion is not significant to brand association. In addition, consumer age differences also moderate the effect of individual attitude towards advertising on brand association (hypothesis $7 \mathrm{~d}$ ) in which the effect of individual attitude is not significant to younger consumers.

Overall results indicate that gender and age differences do not moderate the effect of sales promotion and advertising on brand association nor the effect of brand association on brand loyalty. Women, men, younger and older consumers behave differently towards sales promotion and advertising as suggested by Hew et al. (2017). Men are more affected by non-monetary promotion than women. Conversely, although the result is not significant at $p$-value 0.10 , the difference in coefficient of monetary promotion indicates that women are more affected by this type of promotion while the coefficient is negative in men. The results are consistent with Mazumdar \& Papatla (1995) and Harmon \& Hill (2003) that women are more affected by monetary promotions, including coupons. The plausible explanation is due to the role of women as the person responsible for the family financially, so that they tend to spend the money with full consideration.

However, Harmon \& Hill (2003) prove that the effect of non-monetary promotion may differ on the type of promotions provided. For example, rebates are more gender neutral than coupons. More rebates are given for non-grocery products. In this study, the monetary effect covers price reduction, cashback (rebates) and we 
surprisingly find that women tend to be more affected by this kind of monetary promotions. Non-monetary in this study includes additional items and gifts. Kwon \& Kwon (2007) further mentions that women and men respond differently to certain types of promotions as they refer to female and masculine identity. Female identity is more easily affected by transaction value, whereas masculine identity is more affected by acquisition utility. Therefore, men are more affected by rebates and non-monetary promotions than women.

Furthermore, empirical analysis indicates that the younger group is more affected by non-monetary promotions than the older group. In contrast, monetary promotions only affect the older group. Lambert-Pandraud, Laurent, \& Lapersonne (2005) suggest that the older group is more loyal to brands than the younger group. It causes the younger group to be more price sensitive than older consumers. In addition, the older group tends to have higher income (Lee, 1997). However, surprisingly in this study, we find the opposite that non-monetary promotion highly affects the younger group. It is because the younger group in this study includes consumers less than 20 years old and most of consumers at this age level are high school and university students who have not made their own income. This consumer group uses their parents' money to make purchases. Therefore, they are more non price elastic in comparison with older consumers.

This study provides information to the smartphone managers of the powerful effect of non-monetary promotions and individual attitudes in shaping brand associations that will ultimately shape consumer loyalty. The effect of promotion in the form of free items and gifts on consumer brand equity is relatively higher than on monetary promotions such as discounts, rebates, or coupons. In addition, the effect of ad quality and its creativity is higher than either the media employed or the frequency of advertising given. The results of this study will be useful for managers in determining the appropriate type of promotions based on consumers' gender and ages. Men are more influenced by non-monetary promotions while women are otherwise.

Conclusion

tIn this study, we examine the relationship between sales promotion and advertising to brand association and brand loyalty by taking into consideration gender and age as moderating variables. The empirical results indicate that non-monetary promotion and individual attitude towards advertising significantly affect brand association. Brand association significantly affects brand loyalty. Gender and age-specific analysis indicates that gender differences only significantly moderate the effect of individual attitude towards advertising on brand association while age differences only significantly moderate the effect of monetary promotion on brand association. Separate analyses indicate that women, men, younger and older consumers behave differently towards sales promotions and advertising, that men and the older groups are more affected by non-monetary promotions while women and the younger groups are more affected by non-monetary promotions. The limitations of this study are in terms of a relatively small number of samples. Using large samples for further research is strongly recommended to gain broader representation in each gender and age group.

\section{REFERENCES}

[1] Aaker, D. A. (2009). Managing brand equity. Simon and Schuster.

[2] Agarwal, S., \& Teas, R. K. (2002). Cross-national applicability of a perceived quality model. Journal of Product \& Brand Management, 11(4), 213-236.

[3] Akanbi, P. A., \& Adeyeye, T. C. (2011). The association between advertising and sales volume: a case study of nigerian bottling company plc. Journal of Emerging Trends in Economics and Management Sciences, 2(2), 117-123.

[4] Arum, N. S. (2013). Ini 4 strategi Samsung pertahankan posisi no.1. Retrieved from: https://industri.bisnis.com/read/20131003/105/166841/ini-4-strategi-samsung-pertahankan-posisi-no1 (5 September 2019).

[5] Bovée, C.L. 1992. Contemporary advertising. William F. Arens.

[6] Boyland, E. J., \& Halford, J. C. (2013). Television advertising and branding. Effects on eating behaviour and food preferences in children. Appetite, 62, 236-241. DOI: 10.1016/j.appet.2012.01.032

[7] Bruine de Bruin, W., Parker, A. M., \& Fischhoff, B. (2007). Individual differences in adult decision-making competence. Journal of personality and social psychology, 92(5), 938. DOI: 10.1037/0022-3514.92.5.938

[8] Buil, I., De Chernatony, L., \& Martínez, E. (2013). Examining the role of advertising and sales promotions in brand equity creation. Journal of Business Research, 66(1), 115-122. DOI: 10.1016/j.jbusres.2011.07.030

[9] Chu, S., \& Keh, H. T. (2006). Brand value creation: Analysis of the interbrand-business week brand value rankings. Marketing Letters, 17(4), 323-331. DOI: 10.1007/s11002-006-9407-6 
[10] DelVecchio, D., Henard, D. H., \& Freling, T. H. (2006). The effect of sales promotion on post-promotion brand preference: A meta-analysis. Journal of retailing, 82(3), 203-213. DOI: 10.1016/j.jretai.2005.10.001

[11] Ellen, P., Hess Thomas, M., Daniel, V., \& Corinne, A. (2007). Adult age differences in dual information processes. Perspectives on Psychological Science, 2(1), 1-23. DOI: 10.1111/j.1745-6916.2007.00025.x

[12] Fornell, C., \& Larcker, D. F. (1981). Evaluating structural equation models with unobservable variables and measurement error. Journal of marketing research, 18(1), 39-50. DOI: $10.2307 / 3151312$

[13] Finucane, M. L., Slovic, P., Hibbard, J. H., Peters, E., Mertz, C. K., \& MacGregor, D. G. (2002). Aging and decision-making competence: An analysis of comprehension and consistency skills in older versus younger adults considering health-plan options. Journal of Behavioral Decision Making, 15(2), 141-164. DOI: $10.1002 / \mathrm{bdm} .407$

[14] Forbes. (2019). The largest technology companies In 2019: Apple reigns as smartphones slip and cloud services thrive. Retrieved from: https://www.forbes.com/sites/jonathanponciano/2019/05/15/worldslargest-tech-companies-2019/\#3d33ebe2734f (4 September 2019).

[15] Goodrich, K. (2014). The gender gap: Brain-processing differences between the sexes shape attitudes about online advertising. Journal of Advertising Research, 54(1), 32-43. DOI: 10.2501/JAR-54-1032-043

[16] Greenleaf, E.A., \& Lehmann, D.R. (1995). Reasons for substantial delay in consumer decision making. J. Consum. Res. 22, 186-199, September.

[17] Harmon, S. K., \& Jeanne Hill, C. (2003). Gender and coupon use. Journal of Product \& Brand Management, 12(3), 166-179. DOI: 10.1108/10610420310476924

[18] Hasan, B. (2010). Exploring gender differences in online shopping attitude. Computers in Human Behavior, 26(4), 597-601. DOI: 10.1016/j.chb.2009.12.012

[19] Henseler, J., Ringle, C. M., \& Sinkovics, R. R. (2009). The use of partial least squares path modeling in international marketing. In New challenges to international marketing (pp. 277-319). Emerald Group Publishing Limited.

[20] Hew, J. J., Badaruddin, M. N. B. A., \& Moorthy, M. K. (2017). Crafting a smartphone repurchase decision making process: Do brand attachment and gender matter?. Telematics and Informatics, 34(4), 3456. DOI: 10.1016/j.tele.2016.12.009

[21] Huang, Z., \& Benyoucef, M. (2017). The effects of social commerce design on consumer purchase decision-making: An empirical study. Electronic Commerce Research and Applications, 25, 40-58. DOI: 10.1016/j.elerap.2017.08.003

[22] IDC. (2016). Smartphone vendor. Retrieved from: https://www.idc.com/promo/smartphone-marketshare/vendor (31 May 2018).

[23] Jeong, E., \& Jang, S. S. (2016). Imagine yourself being healthy: The mental simulation effect of advertisements on healthy menu promotion. International Journal of Hospitality Management, 53, 81-93. DOI: 10.1016/j.ijhm.2015.11.005

[24] Keller, K. L., \& Lehmann, D. R. (2003). How do brands create value?. Marketing management, 12(3), 2626.

[25] Keller, K. L., Parameswaran, M. G., \& Jacob, I. (2011). Strategic brand management: Building, measuring, and managing brand equity. Pearson Education India.

[26] Klimes. (2019). Samsung electronics. Retrieved from: http://www.klimes.eu/products/passive-components/samsung-electronics-4.html (4 September 2019).

[27] Kotler, P \& Armstrong, G. (1997). Marketing an introduction. New Jersey: Prentice Hall International 4th edition.

[28] Kotler, P., \& Keller, K. L. (2007). Marketing management 12. Vyd, Praha.

[29] Kotler, P., \& Armstrong. (2008). Principles of Marketing 12th edition. New Jersey: Prentice Hall.

[30] Kotler, P., \& Armstrong, G. (2010). Principles of marketing. Pearson education.

[31] Kwon, K. N., \& Kwon, Y. J. (2007). Demographics in sales promotion proneness: a socio-cultural approach. ACR North American Advances.

[32] Lambert-Pandraud, R., Laurent, G., \& Lapersonne, E. (2005). Repeat purchasing of new automobiles by older consumers: Empirical evidence and interpretations. Journal of Marketing,69(2), 97-113.

[33] Laroche, M., Kim, C., \& Zhou, L. (1996). Brand familiarity and confidence as determinants of purchase intention: An empirical test in a multiple brand context. Journal of business Research, 37(2), 115-120.

[34] Latan, H., \& Ramli, N. A. (2013). The results of partial least squares-structural equation modelling analyses (PLS-SEM). Retrieved from SSRN 2364191.

[35] Lee, R. A. (1997). The youth bias in advertising. American Demographics, 19(1), 46-49.

[36] Loo, R. (2000). A psychometric evaluation of the general decision-making style inventory. Personality and individual differences, 29(5), 895-905. DOI: 10.1016/S0191-8869(99)00241-X

[37] Luxton, S., \& Brito, P. Q. (2015). The Role of Sales Promotion: A Multi-Cultural Comparison between Australia and Portugal. In Proceedings of the 1998 Multicultural Marketing Conference (pp. 121-126). Springer, Cham. 
[38] Mazumdar, T., \& Papatla, P. (1995). Gender difference in price and promotion response. Pricing Strategy \& Practice, 3(1), 21.

[39] Moorthy, S., \& Hawkins, S. A. (2005). Advertising repetition and quality perception. Journal of Business Research, 58(3), 354-360. DOI: 10.1016/S0148-2963(03)00108-5

[40] Nettelhorst, S. C., \& Brannon, L. A. (2012). The effect of advertisement choice on attention. Computers in Human Behavior, 28(2), 683-687. DOI: 10.1016/j.chb.2011.11.015

[41] Oliver, R. L. (2014). Satisfaction: A behavioral perspective on the consumer. Routledge.

[42] Palazon, M., \& Delgado-Ballester, E. (2009). Effectiveness of price discounts and premium promotions. Psychology \& Marketing, 26(12), 1108-1129. DOI: 10.1002/mar.20315

[43] Pappu, R., Quester, P. G., \& Cooksey, R. W. (2005). Consumer-based brand equity: improving the measurement-empirical evidence. Journal of Product \& Brand Management,14(3), 143-154. DOI: $10.1108 / 10610420510601012$

[44] Putrevu, S. (2014). Effects of mood and elaboration on processing and evaluation of goal-framed appeals. Psychology \& Marketing, 31 (2), 134-146. DOI: 10.1002/mar.20682

[45] Rowley,J. (1998). Promotion and Marketing Communications in the Information. Library Review, 47(8), 383-387. DOI: $10.1108 / 00242539810239543$

[46] Santini, F. D. O., Sampaio, C. H., Perin, M. G., \& Vieira, V. A. (2015). An analysis of the influence of discount sales promotion in consumer buying intent and the moderating effects of attractiveness. Revista de Administração (São Paulo), 50(4), 416-431. DOI: 10.5700/rausp1210

[47] SHAMS. (2016). Samsung Company. Retrieved from: http://www.shams.co.com/en/partner-companies/samsung-company/ (4 April 2018).

[48] Strough, J., Cheng, S., \& Swenson, L. M. (2002). Preferences for collaborative and individual everyday problem solving in later adulthood. International Journal of Behavioral Development, 26(1), 26-35. DOI: 10.1080/01650250143000337

[49] Stroup, A. M., \& Branstetter, S. A. (2018). Effect of e-cigarette advertisement exposure on intention to use e-cigarettes in adolescents. Addictive behaviors, 82, 1-6. DOI: 10.1016/j.addbeh.2018.02.021

[50] Sun, Y., Fang, Y., \& Lim, K. H. (2012). Understanding sustained participation in transactional virtual communities. Decision Support Systems, 53(1), 12-22. DOI: 10.1016/j.dss.2011.10.006

[51] Tamres, L. K., Janicki, D., \& Helgeson, V. S. (2002). Sex differences in coping behavior: A meta-analytic review and an examination of relative coping. Personality and social psychology review, 6(1), 2-30. DOI: 10.1207/S15327957PSPR0601_1

[52] Tellis, G. J. (1998). Advertising and sales promotion strategy. Prentice Hall.

[53] Thomas, M., \& Menon, G. (2007). When internal reference prices and price expectations diverge: The role of confidence. Journal of Marketing Research, 44(3), 401-409.

[54] Valette-Florence, P., Guizani, H., \& Merunka, D. (2011). The impact of brand personality and sales promotions on brand equity. Journal of Business Research, 64(1), 24-28. DOI: 10.1016/j.jbusres.2009.09.015

[55] Verhaeghen, P., Marcoen, A., \& Goossens, L. (1993). Facts and fiction about memory aging: A quantitative integration of research findings. Journal of gerontology, 48(4), 157-171. DOI: 10.1093/geronj/48.4.p157

[56] Wardani, A. S. (2019). Samsung Kuasai 66 Persen Pasar Smartphone Premium di Indonesia. Retrieved from: https://www.liputan6.com/tekno/read/4043558/samsung-kuasai-66-persen-pasar-smartphonepremium-di-indonesia (4 September 2019).

[57] Yamin, S., \& Kurniawan, H. (2011). Generasi Baru Mengolah Data Penelitian dengan Partial Least Square Path Modeling Aplikasi dengan Software XLSTAT, SmartPLS, dan Visual PLS. Jakarta: Salemba Infotek.

[58] Yang, J. C., \& Chen, S. Y. (2010). Effects of gender differences and spatial abilities within a digital pentominoes game. Computers \& Education, 55(3), 1220-1233. DOI: 10.1016/j.compedu.2010.05.019

[59] Yoo, B., Donthu, N., \& Lee, S. (2000). An examination of selected marketing mix elements and brand equity. Journal of the academy of marketing science, 28(2), 195-211. DOI: 10.1177/0092070300282002

Received: 2018-11-13

Revision requested: 2019-03-27

Revised: 2019-06-20 (3 revisions)

Accepted: 2020-02-27 


\section{"}

Etty Susilowati

Budiluhur University, Faculty of Economics and Business, International Business and Management Studies, Indonesia e-mail: ettysslwt@gmail.com

Etty Susilowati is a lecturer with a PhD in strategic management. Since 2017, she has been employed at the Faculty of Economics and Business,

Budiluhur University, Indonesia. Her area of expertise is strategic and financial management. Besides, she has years of experience as a director and senior specialist in the fields of marketing, financing, and business in various private and state-owned companies in Indonesia.

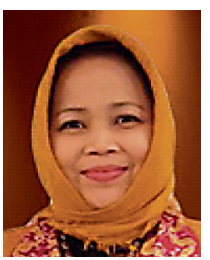

Mohammad Guntur Ardhita Putra

Budiluhur University, Faculty of Economics and Business, International Business and Management Studies, Indonesia e-mail: gunturardhita216@gmail.com

Mohammad Guntur Ardhita Putra is a student of International Business and Management Studies at the Faculty of Economics and Business, Budiluhur University, Indonesia.

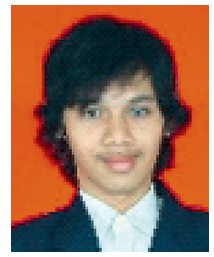

Appendix A

Table A.1: Variable measurements

\begin{tabular}{|c|c|c|}
\hline Latent variables & Labels & Manifest variables \\
\hline \multirow{6}{*}{$\begin{array}{l}\text { Monetary promotion } \\
\text { (Buil et al., 2013) }\end{array}$} & $\mathrm{X} 1$ & Samsung lowered its product price over time \\
\hline & $\mathrm{X} 2$ & Samsung gives a promotional price for a certain period of time \\
\hline & X3 & Samsung often gives price reduction \\
\hline & $\mathrm{X} 4$ & Samsung provides cashback \\
\hline & $\mathrm{X} 5$ & Cashback is satisfactory \\
\hline & $\mathrm{X} 6$ & $\begin{array}{l}\text { Cashback is one of the advantages of all kind of Samsung } \\
\text { promotions }\end{array}$ \\
\hline \multirow{3}{*}{$\begin{array}{l}\text { Non-Monetary promotion } \\
\text { (Buil et al., 2013) }\end{array}$} & $\mathrm{X} 7$ & Samsung gives additional items for each purchase \\
\hline & $\mathrm{X} 8$ & Samsung gives free gifts for each purchase \\
\hline & X9 & Free gifts and additional items are very interesting \\
\hline \multirow{2}{*}{$\begin{array}{l}\text { Perceived advertising (Buil } \\
\text { et al., 2013) }\end{array}$} & $\mathrm{X} 10$ & Samsung provides a variety of online advertising \\
\hline & $\mathrm{X} 11$ & Samsung uses online internet as its advertising medium \\
\hline \multirow{3}{*}{$\begin{array}{l}\text { Individual attitude towards } \\
\text { advertising (Buil et al., } \\
\text { 2013) }\end{array}$} & $\mathrm{X} 12$ & Samsung tv commercial is memorable \\
\hline & $\mathrm{X} 13$ & $\begin{array}{l}\text { Samsung shows the advantages of its smartphones in } \\
\text { television advertising }\end{array}$ \\
\hline & $\mathrm{X} 14$ & Samsung television advertising has a unique concept \\
\hline \multirow{3}{*}{$\begin{array}{l}\text { Brand association (Keller \& } \\
\text { Lehmann, 2003; Pappu et } \\
\text { al., 2005; Buil et al., 2013) }\end{array}$} & $\mathrm{X} 15$ & Samsung company has a credibility \\
\hline & $\mathrm{X} 16$ & $\begin{array}{l}\text { I have a clear image of the type of person who use Samsung } \\
\text { products }\end{array}$ \\
\hline & $\mathrm{X} 17$ & Samsung has a personality and is interesting \\
\hline \multirow{3}{*}{$\begin{array}{l}\text { Brand loyalty (Keller \& } \\
\text { Lehmann, 2003; Pappu et } \\
\text { al., 2005; Buil et al., 2013) }\end{array}$} & $\mathrm{X} 18$ & I always want to purchase a new type of Samsung smartphone \\
\hline & $\mathrm{X} 19$ & Samsung becomes my first choice \\
\hline & $\mathrm{X} 20$ & I prefer Samsung to other brands \\
\hline
\end{tabular}

